\title{
English Writing Formative Assessment in Indonesia
}

\begin{abstract}
This study aimed to investigate the assessment techniques used by a teacher in assessing students' writing skills, the reason in implementing the techniques, and the students' responses toward the implementation of the techniques. The collected data in this study included classroom observation that had been held in three times, interview, and written document. The following is the conclusions based on the data analysis. Since formative assessment of writing skill is the main focus of this study, the teacher implemented five writing performance tasks suggested by Brown (2010) namely dicto-comp, picture-cued task, short answer task, guided question and answer, and paragraph construction task. From the teaching process done by the teacher, the assessment tasks were implemented for formative purposes, that is, to monitor students' progress in comprehending the lesson that is about narrative text. The teacher implemented some assessment tasks in an informal way to monitor students' ongoing progress without recording the result of the performance, while the other tasks were implemented in a formal way to record students' progress and to give them an appraisal of their progress and achievement.
\end{abstract}

Keywords: English writing, Formative assessment, EFL students

\section{Introduction}

In educational context, assessment and teaching process are inseparable. As suggested by Jabbarifar, assessment focuses on diverse aspects of teaching and learning, including respective textbooks and instructional materials, student achievement, and whole program instruction. Some experts consider assessment as a necessary aspect of teaching and learning. Pellegrino, for instance, suggest that assessment is required to monitor students' attitude and collect information to draw a rational conclusion about students' knowledge. Many scholars support the notion that assessment is beneficial for teachers in order to adjust the teaching methods and techniques as long as it is handled judiciously. Many teachers also believe that assessment is a vital instrument in making students concentrate their effort in learning, making students confident in their final examination and usefulness of feedback in enhancing students' performance.

Despite the highly useful aspects of assessment, it cannot be ignored that teachers sometimes face difficulties in assessing students' writing skill. Since language skills include four aspects (listening, speaking, reading, and writing) and all these skills integrated to one another, teachers need to put extra effort in designing and administering the assessment techniques. As stated by Brown (2010) that "the integration of skills is of paramount importance in language learning”. 
Furthermore, if students are not involved in the assessment process, it means that the assessment is not implemented to its full effectiveness. Hence, O’ Farrell (2004) suggests that in creating assessment plans, teachers need to prioritize the prominent area of students' lesson, create distinct learning outcomes, and assess appropriately. If the assessment is not designed properly, it may reveal little or no progress and discourage students. Pellegrino et al. (2001) even adds that effective teachers need to use varied forms of assessment as well as to provide feedback on students' progress. Moreover, teachers need to design an assessment plan effectively and efficiently in order to get an authentic result of students' progress in writing skill and to provide feedback in enhancing students' performance. A number of experts had been conducted studies concerning Formative assessment or writing skill. Some of them conducted studies in the area of classroom assessment, and perceptions of assessment. Those previous studies are as follows. Jabbarifar (2009) conducted a study which was aimed to look at the importance of classroom assessment and evaluation advantages as well as to present some useful assessment and evaluation techniques which can assist language teachers to create dynamic classroom situation for evaluation. Ramadani (2014) also conducted a study to investigate the assessment techniques used by teachers in assessing students' speaking skill. Another study came from Ndalichako (2015) which investigated perceptions that teachers have in the assessment that are likely to influence their assessment practices. Mussawy (2009) also attempted to explore preservice teachers' perceptions of classroom assessment and the faculty members' perceptions of classroom assessment as well as their expectations of students' learning.

Although several studies concerning the assessment process have been conducted, it is still lack of studies concerning the assessment techniques about formative assessment in writing skill. Therefore, this study aims to fill the gap by analyzing formative assessment in writing skills. In addition, this study aims to reveal the teacher's reason for implementing the techniques as well as the students' responses of the implementation of the techniques. By conducting this study, it will be revealed whether the teacher used varied forms of assessment and whether the assessment is implemented to its full effectiveness.

\section{Methodology}


This research was guided by a qualitative research design as this study attempted to describe the assessment techniques used by a teacher in assessing students' language skills. Qualitative research, as stated by Creswell (2014), refers to "an approach for exploring and understanding the meaning individuals or groups ascribe to a social or human problem". According to Denzin \& Lincoln, qualitative research is appropriate to employ because it attempts to study things in their natural settings, to make sense of, or interpret, phenomena in terms of the meanings people bring to them (in Creswell, 2013).

\section{Research Site and Participants}

This research was conducted in a junior high school. There are two reasons why the school was chosen as the setting for this study. First, the teacher in that school was willing to do the research. Second, the school was chosen for its availability since the authority of the school allowed the researcher to conduct the research at that time. Meanwhile, the participants involved in this study were an English teacher and a class of ninth grade of junior high school students.

\section{This research employed some data collection techniques in order to collect the data.}

The techniques used are classroom observation, interview, and written document. This is in line with Klenke (2016) who believes that "multiple instruments are typically employed to collect data for case studies, including interviews, use of archival data or documents, or participant observation". The detail process of data collection will be described below.

\section{Classroom Observation}

The first instrument employed in order to answer the research question was classroom observation. According to Cowie, "Observation is the conscious noticing and detailed examination of participants' behavior in a naturalistic setting". Observation commonly takes the form of two ideal types including participant and non-participant. The type of observation conducted in this study was non-participant observation, where the researcher observed without

participating and separated from the phenomenon. To help the researcher to observe all the classroom activities and to complete the information, video recording was used in this study. It was a rich source since it captured all the things happened or emerged during the classroom observation. The data of classroom observation that was recorded on the video recorder was converted to video transcription. The researcher conducted the observation in a class of ninth grade. There were three observational visits for 100 minutes (2 learning hours) in each visit. The observational visits were intended to discover what kind of assessment techniques used by the 
teacher in assessing students' writing skill. It was seen through teacher-students' interaction and the whole classroom activity.

\section{Conclusion}

Based on the observation, the tasks implemented by the teacher were integrated with each other to achieve the main objective of the lesson, that is, students are able to write a narrative story by their own words individually. However, the results of the study portrayed some examples of assessment task that involved writing performance. Hence, the teacher implemented dicto-comp in the first meeting to familiarize students with some narrative texts. Short answer task along with guided question and answer were implemented to check students' comprehension of the texts and whether they absorbed the information well. Then, the picture-cued task was implemented in the second meeting to gain the students' interest in learning the generic structure of narrative text by providing pieces of comics. By conducting the picture-cued task, the teacher was able to give them a practice on how to analyze generic structures and language features of the narrative text. At last, paragraph construction task was implemented to check students' individual capability in writing a narrative story.

\section{References}

Albana, H. H., Marzuki, A. G., Alek, A., \& Hidayat, D. N. (2020). Cohesive Devices in Student's Writing (A Discourse Analysis on Argumentative Text). Jurnal Pendidikan Humaniora, 8(1), 6-11.

Alek, A., Marzuki, A. G., Farkhan, M., \& Deni, R. (2020). Self-Assessment in Exploring EFL Young learners' Speaking Skill. Al-Ta lim Journal, 27(2), 208-214.

Alek, A., Marzuki, A. G., Farkhan, M., Surahman, D., Daryanto, D., \& Febrianto, S. (2020). Computer Based Testing in Senior High School on National Examination. Indonesian Journal of Learning Education and Counseling, 2(2), 204-210. Angeles: University of California.

Belanger, J. (2004). 'When Will We Ever Learn?': The Case for Formative Assessment Supporting Writing Development. English in Australia, (141), 41.

Brown, H. D. (2010). Language Assessment: Principles and Classroom Practices (Second Edi). New York: Pearson Education Inc.

Burner, T. (2016). Formative assessment of writing in English as a foreign language. Scandinavian Journal of Educational Research, 60(6), 626-648.

Burner, T. (2016). Formative assessment of writing in English: A school-based study of perceptions, practices and transformations. 
Chappuis, S., Stiggins, R., Arter, J., \& Chappuis, J. (2004). Assessment for Learning. Portland: Assessment Training Institute.

Fatimah, A. S., Santiana, S., \& Saputra, Y. (2019). Digital Comic: An Innovation of Using Toondoo As Media Technology for Teaching English Short Story. English Review: Journal of English Education, 7(2), 101-108.

Frey, N., \& Fisher, D. (2013). A formative assessment system for writing improvement. English Journal, 66-71.

Furtak, E. M., \& Ruiz-Primo, M. A. (2008). Making students' thinking explicit in writing and discussion: An analysis of formative assessment prompts. Science Education, 92(5), 799824.

Garrison, C., Ehringhaus, M. (2013). Formative and Summative Assessments in the Classroom. Association for Middle Level Education. Retrieved from https://www.amle.org/BrowsebyTopic/WhatsNew/WNDet/TabId/270/ ArtMID/888/ArticleID/286/Formative-and-Summative-Assessmentsin-theClassroom.aspx

Graham, S., Harris, K., \& Hebert, M. A. (2011). Informing writing: The benefits of formative assessment. A Carnegie Corporation Time to Act report. LI RESEARCH ARCHIVES ONLINE.

Graham, S., Hebert, M., \& Harris, K. R. (2015). Formative assessment and writing: A metaanalysis. The Elementary School Journal, 115(4), 523-547.

Horstmanshof, L., \& Brownie, S. (2013). A scaffolded approach to discussion board use for formative assessment of academic writing skills. Assessment \& Evaluation in Higher Education, 38(1), 61-73.

Keen, J. (2005). Assessment for writing development: Trainee English teachers' understanding of formative assessment. Teacher Development, 9(2), 237-253.

Klute, Mary. (2017). Formative assessment and elementary school student academic achievement: A review of the evidence. U.S. Department of EducationR EL 2017-259

Korkmaz, S., \& Öz, H. (2021). Using Kahoot to Improve Reading Comprehension of English as a Foreign Language Learners. International Online Journal of Education and Teaching, 8(2), 1138-1150.

Kuliahana, A., \& Marzuki, A. G. (2020). Repetition Technique in an EFL Speaking Class in Islamic Higher Education in Indonesia. Academic Journal Perspective: Education, Language, and Literature, 8(1), 20-28.

Landauer, T. K., Lochbaum, K. E., \& Dooley, S. (2009). A new formative assessment technology for reading and writing. Theory into Practice, 48(1), 44-52.

Lee, I. (2011). Formative assessment in EFL writing: An exploratory case study. Changing English, 18(1), 99-111.

Marzuki, A. G. (2019). The Implementation of SQ3R Method to Develop Learners' Reading Skill on Islamic Texts in EFL Class in Indonesia. Register Journal, 12(1), 49-61. 
Marzuki, A. G. (2019). Utilizing Recorded English Dialogues in Teaching English Word Stress to Islamic Higher Education Learners in Indonesia. Jurnal Pendidikan Islam, 5(1), 53-64.

Marzuki, A. G., Alim, N., \& Wekke, I. S. (2018). Improving the reading comprehension through cognitive reading strategies in language class of coastal area in indonesia. In IOP Conference Series: Earth and Environmental Science, 156(1), 012050). IOP Publishing.

Marzuki, A.G. (2016). Utilizing cooperative learning in islamic college learners' classroom. IJEE (Indonesian Journal of English Education), 3(2), 123-139.

Marzuki, A.G. (2017). Developing speaking skill through oral report in an efl class in indonesia. Al-Ta lim Journal, 24(3), 243-254.

Marzuki, A.G. (2017). Utilizing pictures in increasing learners' vocabulary mastery in an efl class in palu city indonesia. Musawa: Journal for Gender Studies, 9(2), 191-233.

Mohamadi, Z. (2018). Comparative effect of online summative and formative assessment on EFL student writing ability. Studies in Educational Evaluation, 59, 29-40.

Mussawy, S., A., J. (2009). Assessment Practices: Student' s and Teachers 'Perceptions of Classroom Assessment University of Massachusetts School of Education, 1-115.

Reising, B. (1997). The formative assessment of writing. The Clearing House, 71(2), 71-72.

Saeed Alharbi, A., \& Meccawy, Z. (2020). Introducing Socrative as a Tool for Formative Assessment in Saudi EFL Classrooms. Arab World English Journal (AWEJ) Volume, 11.

Santiana, S., \& Fatimah, A. S. (2017). Prezi, Cloud-Based Presentation, for Teaching: How is it Interesting?. EduLite: Journal of English Education, Literature and Culture, 2(2), 445456.

Wragg, E. C. (2003). Assessment and Children's Learning in the Secondary School. London: RoutledgeFalmer.Ndalichako, J. L. (2015). Secondary School Teachers' Perceptions of Assessment. International Journal of Information and Education Technology, 5(5), 326330. https://doi.org/10.7763/IJIET.2015.V5.524 
